\title{
Typical and atypical antipsychotic drugs increase extracellular histamine levels in the rat medial prefrontal cortex: contribution of histamine $\mathrm{H}_{1}$ receptor blockade
}

\author{
Matthew J. Fell ${ }^{1+}$, Jason S. Katner ${ }^{1}$, Kurt Rasmussen ${ }^{1}$, Alexander Nikolayev ${ }^{2}$, Ming-Shang Kuo ${ }^{2}$, \\ David L. G. Nelson ${ }^{1}$, Kenneth W. Perry ${ }^{1}$ and Kjell A. Svensson ${ }^{1}{ }^{*}$
}

1 Psychiatric Disorders, Neuroscience Discovery Research, Eli Lilly and Company, Indianapolis, IN, USA

${ }^{2}$ Translational Science, Eli Lilly and Company, Indianapolis, IN, USA

Edited by:

Bernat Kocsis, Harvard Medical

School, USA

\section{Reviewed by:}

Francesc Artigas, Instituto de Investigaciones Biomédicas de Barcelona, Spain

Ritchie Brown, Harvard Medical School, USA

\section{${ }^{*}$ Correspondence:}

Kjell A. Svensson, Neuroscience Discovery Research, Lilly Research Laboratories, Lilly Corporate Center, Indianapolis, IN 46285, USA.

e-mail: svenssonka@lilly.com

\section{${ }^{\dagger}$ Present address:}

Matthew J. Fell, Neurodegenerative Diseases, Merck Research

Laboratories, 2015 Galloping Hill

Road, Kenilworth, NJ 07033, USA.
Atypical antipsychotics such as clozapine and olanzapine have been shown to enhance histamine turnover and this effect has been hypothesized to contribute to their improved therapeutic profile compared to typical antipsychotics. In the present study, we examined the effects of antipsychotic drugs on histamine (HA) efflux in the mPFC of the rat by means of in vivo microdialysis and sought to differentiate the receptor mechanisms which underlie such effects. Olanzapine and clozapine increased MPFC HA efflux in a dose related manner. Increased HA efflux was also observed after quetiapine, chlorpromazine, and perphenazine treatment. We found no effect of the selective 5-HT $2 \mathrm{~A}$ antagonist MDL100907, $5-\mathrm{HT}_{2 \mathrm{c}}$ antagonist SB242084, or the 5- $\mathrm{HT}_{6}$ antagonist Ro 04-6790 on mPFC HA efflux. $\mathrm{HA}$ efflux was increased following treatment with selective $\mathrm{H}_{1}$ receptor antagonists pyrilamine, diphenhydramine, and triprolidine, the $\mathrm{H}_{3}$ receptor antagonist ciproxifan and the mixed $5-\mathrm{HT}_{2 \mathrm{~A}} / \mathrm{H}_{1}$ receptor antagonist ketanserin. The potential novel antipsychotic drug FMPD, which has a lower affinity at $\mathrm{H}_{1}$ receptors than olanzapine, did not affect $\mathrm{HA}$ efflux. Similarly, other antipsychotics with lower $\mathrm{H}_{1}$ receptor affinity (risperidone, aripiprazole, and haloperidol) were also without effect on HA efflux. Finally, HA efflux after antipsychotic treatment was significantly correlated with affinity at $\mathrm{H}_{1}$ receptors whereas nine other receptors, including $5-\mathrm{HT}_{2 \mathrm{~A}}$, were not. These results demonstrate that both typical and atypical antipsychotics increase mPFC histamine efflux and this effect may be mediated via antagonism of histamine $\mathrm{H}_{1}$ receptors.

Keywords: in vivo microdialysis, histamine, clozapine, olanzapine, FMPD, antipsychotic

\section{INTRODUCTION}

Although the introduction of typical antipsychotic drugs in the 1950s revolutionized the treatment of schizophrenia, their use has been impeded by a number of side effects such as extrapyramidal symptoms (EPS), tardive dyskinesia, and their failure to adequately treat the negative and cognitive symptoms in schizophrenia. Atypical antipsychotics such as clozapine, olanzapine, risperidone, ziprasidone, and aripiprazole differ from typical antipsychotic drugs in that they have a reduced liability for EPS and generally do not induce sustained increases in serum prolactin. Some atypical antipsychotics drugs also appear to improve not only the positive symptoms, but may be of benefit in the treatment of negative and cognitive deficits when compared to the typical antipsychotics (Meltzer and Okayli, 1995; Meltzer and McGurk, 1999; Keefe et al., 2007).

Despite much research, the mechanisms responsible for the improved therapeutic profile of atypical antipsychotics drugs compared to typical antipsychotics are not fully understood and the task of unveiling such mechanisms is complicated by the complex receptor pharmacology of antipsychotic drugs. Indeed, typical and atypical antipsychotics differ greatly in terms of their ability to interact with a number of dopaminergic (e.g., $\mathrm{D}_{2}, \mathrm{D}_{3}$, and $\mathrm{D}_{4}$; Seeman and Lee, 1975; Seeman et al., 1997) serotonergic (e.g., 5- $\mathrm{HT}_{1 \mathrm{~A}}, 5-\mathrm{HT}_{2 \mathrm{~A}}, 5-\mathrm{HT}_{2 \mathrm{C}}, 5-\mathrm{HT}_{6}$, and 5- $\mathrm{HT}_{7}$; Roth et al., 1994; Bymaster et al., 1996), adrenergic/muscarinic acetylcholine (Zeng et al., 1997), and histaminergic receptors [e.g., $\mathrm{H}_{1}$ (Peroutka et al., 1980), $\mathrm{H}_{2}$ and $\mathrm{H}_{3}$ (Bymaster et al., 1999; Lovenberg et al., 2000)]. Nevertheless previous preclinical studies have shown that atypical antipsychotic drugs but not typical antipsychotic drugs such as haloperidol or chlorpromazine, preferentially enhance dopamine (DA), norepinephrine, and acetylcholine efflux in the rat medial prefrontal cortex (mPFC) and hippocampus compared with the nucleus accumbens (Li et al., 1998; Kuroki et al., 1999; Zhang et al., 2000; Assié et al., 2005). These effects have been hypothesized to contribute to the enhanced ability of atypical antipsychotic drugs to improve cognitive function and negative symptoms in patients with schizophrenia (Morisset et al., 1999; Huang et al., 2008).

The monoamine histamine is known to function as a neurotransmitter, with neurons originating from the posterior hypothalamus tuberomammillary nucleus (PH-TMN) and projecting to regions that include the cortex, hippocampus, amygdala, and 
striatum. In the brain, histamine exerts it effects through three G-protein coupled receptors: $\mathrm{H}_{1}, \mathrm{H}_{2}$, and $\mathrm{H}_{3}$ and is involved in the regulation of many physiological functions including, the sleep-wake cycle, feeding, arousal, emotion, memory, and cognition (Schwartz et al., 1991; Haas and Panula, 2003; Haas et al., 2008). Despite the role of histamine in many centrally mediated processes relevant to schizophrenia, the effect that antipsychotic drug treatment has on histaminergic neurotransmission has not been extensively studied. One earlier study by Morisset et al. (1999) did however reveal that atypical antipsychotics enhance tissue levels of the histamine metabolite tele-methylhistamine ( $\mathrm{t}-\mathrm{MeHA})$ in the mPFC and striatum of mice. This effect was comparable to that of the potent $\mathrm{H}_{3}$ receptor antagonist ciproxifan and appeared to be selective for atypical antipsychotics drugs as enhanced t-MeHA was not observed after treatment with typical antipsychotics. The mechanism(s) by which atypical antipsychotic drugs modulate histaminergic neurotransmission are unclear but Morisset et al. (1999) hypothesized that it may be related to their greater ability to antagonize $5-\mathrm{HT}_{2 \mathrm{~A}}$ receptors compared to typical antipsychotics (Morisset et al., 1999). These results did provide evidence that atypical antipsychotic drugs can enhance histaminergic activity in limbic brain regions and raised the possibility that in addition to their effects of DA, NE, and Ach, enhanced histaminergic neurotransmission may also contribute to the improved efficacy of atypical antipsychotics.

In the present study, we sought to examine the effects of atypical (olanzapine, clozapine, risperidone, quetiapine, and aripiprazole) and typical (chlorpromazine, perphenazine, and haloperidol) antipsychotic drugs on histamine efflux in the mPFC of the rat by means of in vivo microdialysis. In order to differentiate the receptor mechanism(s) underlying the ability of antipsychotic drugs to modulate histaminergic activity, we also examined the histamine response in the $\mathrm{mPFC}$ to ligands selective for monoaminergic receptors $\left(\mathrm{H}_{1}, \mathrm{H}_{3}, 5-\mathrm{HT}_{2} \mathrm{~A}, 5-\mathrm{HT}_{2} \mathrm{C}, 5-\mathrm{HT}_{6}\right)$ that are targeted by antipsychotic drugs. In addition, we attempted to correlate the changes in mPFC histamine efflux for the antipsychotic drugs studied with their binding affinities at 11 monoaminergic receptors using binding affinities previously determined by the NIMH Psychoactive Drug Screening Program (Roth et al., 2004).

\section{MATERIALS AND METHODS \\ ANIMALS}

All experiments were conducted in accordance with the National Institutes of Health Guide for Care and Use of Laboratory Animals (http://www.nap.edu/readingroom/books/labrats) and were approved by the Eli Lilly Institutional Animal Care and Use Committee. Subjects were male Sprague-Dawley rats (Taconic Germantown, NY, USA) weighing between 250 and $350 \mathrm{~g}$. Rats were singly housed with standard laboratory chow and water available ad libitum and maintained on a 12-h light/dark cycle (lights on at 06:00, lights off at 18:00). All efforts were made to minimize the discomfort and the number of animals used. All experiments were performed between 8 am and 4 pm using appropriate vehicle controls.

\section{MICRODIALYSIS PROCEDURES}

Parts of this microdialysis technique have been previously described (Perry et al., 2008; Fell et al., 2010). However for these experiments all surgeries were carried out by Taconic (Germantown, NY, USA) 5-7 days before the experiment. In brief, the rats were anesthetized with isoflurane gas and mounted in a stereotaxic frame. A microdialysis guide and stylet (BASi, West Lafayette, IN, USA) were stereotaxically placed in the locations given below. The stereotaxic coordinates for the medial prefrontal cortex (PFC) cannula were: A (anterior to bregma), $3.2 \mathrm{~mm}$; L (lateral from the midsagittal suture) $0.8 \mathrm{~mm}$; and $\mathrm{V}$ (ventral from the dura surface), $-2 \mathrm{~mm}$. A concentric type probe $(\mathrm{PFC}=\mathrm{BR}-4)$ from BASi (West Lafayette, IN, USA) to match the implanted cannula with a $4 \mathrm{~mm}$ (PFC) membrane tip extending below the cannula was flushed with water and carefully inserted through the cannula $16 \mathrm{~h}$ before the experiment began. Immediately after insertion of the probe the rat was placed in the cage where the experiment was to be conducted in order to acclimate to the new cage overnight.

On the morning of the experiment the rat's probe was connected to a liquid swivel then to a fraction collection system for freely moving animals [BioAnalytical Systems (BASi), West Lafayette, IN, USA]. The input tube of the dialysis probe was connected to a syringe pump (BASi) which delivered an artificial cerebrospinal fluid containing $150 \mathrm{mM} \mathrm{NaCl}, 3 \mathrm{mM} \mathrm{KCl}$, $1.7 \mathrm{mM} \mathrm{CaCl}_{2}$, and $0.9 \mathrm{mM} \mathrm{MgCl}_{2}(\mathrm{pH} \mathrm{6.0)}$ to the probe at a rate of $1.5 \mu \mathrm{l} / \mathrm{min}$. The output tubes from the rats were attached to a refrigerated fraction collector (BASi). After a period of $2 \mathrm{~h}$ for equilibration of the probe and establishment of stable monoamine baseline levels, collection of $30 \mathrm{~min}$ fractions was started. The flow from the output lines was collected in $200 \mu$ l plastic tubes, $20 \mu \mathrm{l}$ of which was injected onto the HPLC system for histamine analysis. Three baseline samples were collected before injection of any drugs. For the central administration of clozapine or pyrilamine directly into the PFC, both compounds were delivered via the microdialysis probe. After the establishment of a stable baseline, the inlet tubing from a syringe containing aCSF was manually switched to one containing the drug at the appropriate concentration.

\section{BIOCHEMICAL DETERMINATIONS Histamine analysis}

Histamine was analyzed using a modified version of the of the method previously described by Westerink et al. (2002). Histamine was separated on an HPLC column and quantified by fluorimetric detection after a postcolumn derivatization with an $o$-phthaldialdehyde-containing reagent as follows. The mobile phase consisted of $0.16 \mathrm{M} \mathrm{KH} 2 \mathrm{PO} 4,0.1 \mathrm{mM}$ sodium octanesulfonic acid, and $0.1 \mathrm{mM}$ EDTA; the $\mathrm{pH}$ was adjusted to 4.6. The flow rate of the mobile phase was $0.7 \mathrm{ml} / \mathrm{min}$. The eluent line was connected by a T-piece for mixing with a reagent line through which a $0.02 \%$ solution of $o$-phthaldialdehyde $(97 \%$ $\mathrm{OPA}$, Sigma) in $0.15 \mathrm{M} \mathrm{NaOH}$ was delivered at $0.6 \mathrm{ml} / \mathrm{min}$. The OPA reagent was mixed with the eluent in a mixing coil of Teflon tubing (OD $1.1 \mathrm{~mm}$, ID $0.55 \mathrm{~mm}$; length $1 \mathrm{~m}$ ) to allow the derivatization reaction to proceed at ambient temperature. The OPA reagent solution was prepared fresh daily, protected 
from light, and kept cooled in ice. Histamine was separated on a reverse-phase column, a BDS Hypersil, $3 \mu \mathrm{m}, \mathrm{C} 18$ analytical column $(4.6 \times 100 \mathrm{~mm}$ from Thermo-Fisher $)$. The fluorescence of the reaction product was measured by a fluorimeter (Jasco FP-920; excitation: $350 \mathrm{~nm}$; emission: $450 \mathrm{~nm}$ ) set at the highest sensitivity. The sensitivity for histamine was about $20 \mathrm{fmol}$ per sample $(20 \mu \mathrm{l})$.

\section{DRUGS}

Olanzapine, ciproxifan, quetiapine, aripiprazole, ketanserin, SB242048, R0-46 6790, and FMPD [6-Fluoro-10-[3-(2-methox yethyl)-4-methyl-piperazin-1-yl]-2-methyl-4H-3-thia-4,9-diazabenzo[f]azulene] were synthesized at Lilly Research Laboratories (Indianapolis, IN, USA). MDL100907, clozapine, haloperidol, pyrilamine, and diphenhydramine, were obtained from Sigma Aldrich (St. Louis, MO, USA). Risperidone was purchased from Toronto Research Chemicals Inc, North York, Canada. Triprolidine was purchased from Tocris. Clozapine, olanzapine, risperidone, quetiapine, haloperidol, MDL100907, ciproxifan, and FMPD were dissolved in a few drops of an $11.5 \%$ solution of lactic acid and diluted in $0.9 \%$ saline. Pyrilamine, diphenhydramine, and triprolidine were dissolved in sterile water. Unless stated otherwise, all drugs were administered via the subcutaneous route (s.c.) in a volume of $1 \mathrm{ml} / \mathrm{kg}$. Ketanserin and aripiprazole suspended in a solution consisting of $1 \%$ carboxymethylcellulose, $0.25 \%$ Tween 80 , and $0.05 \%$ Dow antifoam and administered orally (p.o.) in a volume of $2 \mathrm{ml} / \mathrm{kg}$. SB242048 and Ro 04-6790 were suspended in a solution consisting of $1 \%$ carboxymethylcellulose, $0.25 \%$ Tween 80 , and $0.05 \%$ Dow antifoam and administered i.p. in a volume of $2 \mathrm{ml} / \mathrm{kg}$. For central administration clozapine was dissolved in a few drops of an $11.5 \%$ solution of lactic acid and diluted aCSF and the $\mathrm{pH}$ adjusted to 7.4 with the drop-wise addition of $5 \mathrm{~N}$ $\mathrm{NaOH}$. Pyrilamine was dissolved in aCSF and the $\mathrm{pH}$ adjusted to 7.4 with the drop-wise addition of $5 \mathrm{~N} \mathrm{NaOH}$. Both compounds were delivered via the microdialysis probe by manually switching the inlet tubing from a syringe containing aCSF to one containing the drug.

The selection of doses for both typical and atypical antipsychotic drugs tested was based on receptor occupancy data (Kapur et al., 2003; Barth et al., 2006; Natesan et al., 2006). For example, the $\mathrm{ED}_{50}$ (dose required to block $50 \%$ of raclopride binding) values for olanzapine, clozapine, haloperidol, risperidone, quetiapine, chlorpromazine, and aripiprazole in the rat brain are $0.57,7.26,0.02$, $0.32,11.8,5.1$, and $0.7 \mathrm{mg} / \mathrm{kg}$ respectively. In addition, the doses of antipsychotic drugs tested for single point investigation have previously been shown to be efficacious in behavioral paradigms including amphetamine induced locomotor activity and conditioned avoidance responding. The doses of the potential novel antipsychotic FMPD were selected on the basis of efficacy in behavioral models as previously described by Rasmussen et al. (2005). The doses of the receptor selective compounds were selected on the basis of ex vivo and in vivo occupancy data for the respective receptors. In the absence of binding data, data from other pharmacological and biochemical assays revealing activity at the respective receptors were used to select relevant doses (Bentley et al., 1999; Morisset et al., 1999; Goudie et al., 2004; Marek et al., 2005; Le et al., 2008).

\section{STATISTICAL ANALYSIS}

All dialysis probe placements were checked by perfusing a tetra red solution through the dialysis probe for subsequent histological examination. Only results derived from rats with correctly positioned probes were included in the data analysis. All microdialysis data were calculated as percent of baseline with $100 \%$ defined as the average of the three drug pre-injection values $(n=5-6$ per group). Time course data represent the percent change from baseline and were analyzed by two-way analysis of variance (ANOVA) followed by post hoc Bonferroni corrected $t$-test. Summary data represent the average percent of baseline $\mathrm{HA}( \pm \mathrm{SEM})$ for the $3.5 \mathrm{~h}$ post-drug or vehicle. Where there were more than two treatment groups the data were subjected to one-way analysis of variance (ANOVA) followed by a post hoc Dunnett's corrected $t$-test. When only two treatment groups were present the data were analyzed by independent samples, two-tailed Student's $t$-test. $K_{i}$ values used in our correlation analysis were determined by the NIMH Psychoactive Drug Screening Program (Roth et al., 2004). The $K_{i}$ values used in our analysis are listed as NIMH Psychoactive Drug Screening Program assay certified data, determined from assays using cloned human or rat receptors with drugs of interest as test ligands. For $K_{i}$ values for which PDSP certified assay data were not listed, we used the average $K_{i}$ value from assay data compiled on the PDSP web site using cloned human and rat receptors with drug of interest as the test ligand (Roth et al., 2004). $K_{i}$ values from cloned human and rat receptors for the potential novel antipsychotic FMPD were identified from a previously published study by Rasmussen et al. (2005). $K_{i}$ values used in our analysis are listed in Tables S1 and S2 in Supplementary Material. All binding data analyzed in our study have been previously reported by other investigators. Percent mPFC histamine efflux and binding affinities $\left(K_{i}\right)$ were log-transformed before analysis. All analyses were performed using the GraphPad PRISM statistical program (GraphPad, San Diego, CA, USA) and the level of significance was set at $P<0.05$.

\section{RESULTS}

BASAL CONCENTRATIONS OF HISTAMINE IN MICRODIALYZATES FROM THE MEDIAL PREFRONTAL CORTEX OF THE RAT

Under the present experimental conditions, average pre-injection, basal histamine concentrations in the mPFC were $4.13 \pm 0.02 \mathrm{nM}$ (based a total of 192 rats used in experiments presented in Figures 1-4; Tables 1 and 2).

\section{EFFECTS OF THE ATYPICAL ANTIPSYCHOTIC DRUGS ON HISTAMINE EFFLUX IN THE mPFC}

The atypical antipsychotic drugs clozapine (Figures 1A,B) and olanzapine (Figures 1C,D) significantly increased extracellular histamine in the mPFC. A two-way ANOVA revealed significant effects of drug, time, and interaction after clozapine treatment: drug $[F(3,160)=46.1 ; P<0.001]$, time $[F(9,160)=7.97$; $P<0.001]$, and drug $\times$ time $[F(27,160)=3.27 ; P<0.001]$ and olanzapine treatment: $\operatorname{drug}[F(3,190)=40.29 ; P<0.001]$, time $[F(9,190)=3.84 ; P<0.001]$, and drug $\times$ time $[F(27,190)=2.67$; $P<0.001]$. Post hoc analysis showed significant increases in HA efflux after clozapine and olanzapine treatment as compared to the vehicle treated group. Analysis of the average percent of 
A

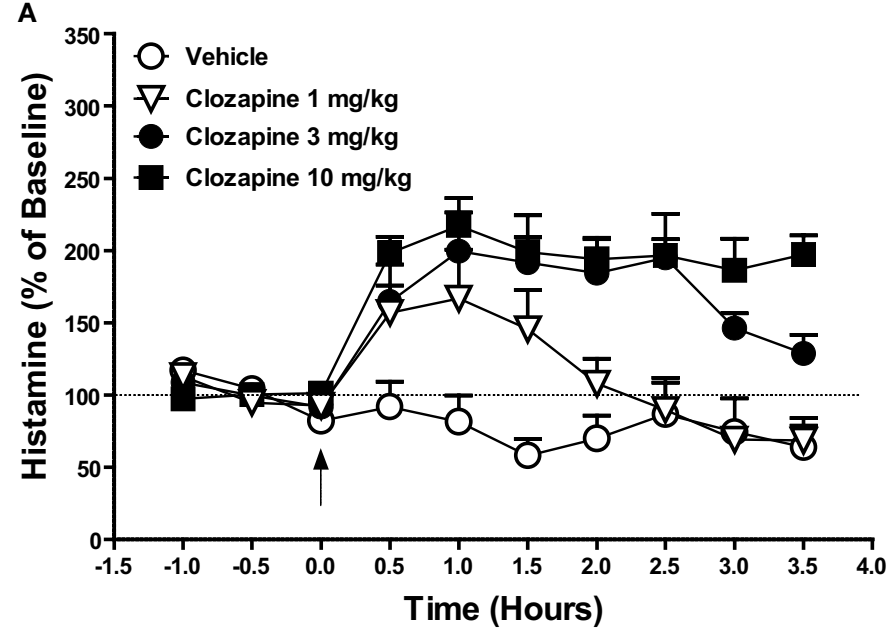

C

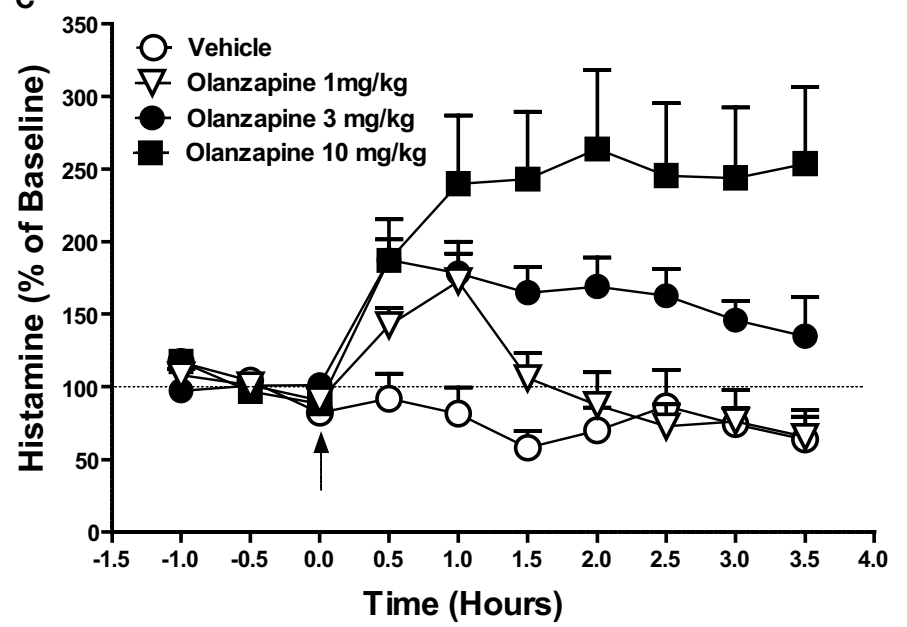

B

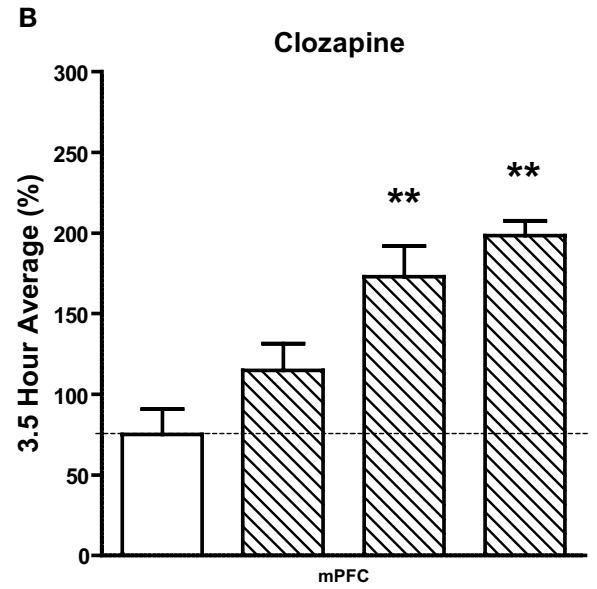

D

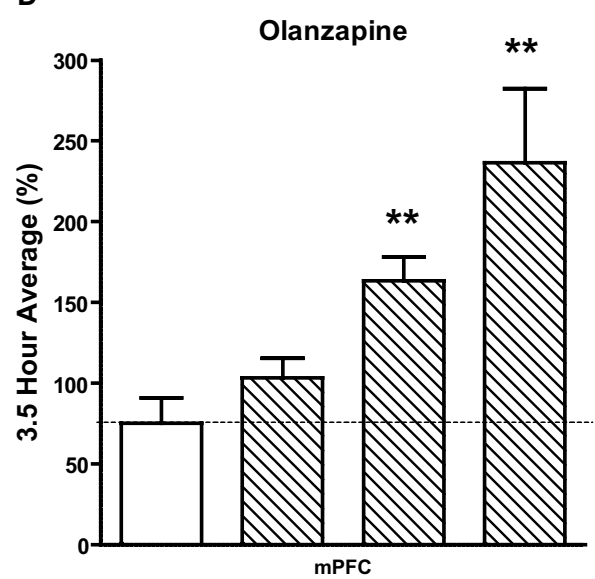

FIGURE 1 | Effect of the atypical antipsychotic drug (A,B) clozapine (1-10 $\mathrm{mg} / \mathrm{kg}$, s.c.) or (C,D) olanzapine (1-10 $\mathrm{mg} / \mathrm{kg}, \mathrm{s.c}$.) on histamine efflux in the $\mathbf{m P F C}$. Data are mean \pm SEM of the dialyzate HA levels, expressed as a percentage of the baseline. Time course data shown in (A) and (C) were analyzed by two-way analysis of variance (ANOVA) followed by post hoc Bonferroni corrected t-test. Summary data (B) and (D) represent average percent of baseline HA ( \pm SEM) for the $3.5 \mathrm{~h}$ post-drug or vehicle and were subjected to one-way analysis of variance (ANOVA) followed by post hoc Dunnett's corrected $t$-test ( $n=5-6$ per group). ${ }^{*} P<0.01$ compared to the vehicle treated animals. baseline over the $3.5 \mathrm{~h}$ post-injection of clozapine (Figure 1B) or (Figure 1D) olanzapine revealed a significant effect of treatment on histamine efflux between groups: clozapine $[F(3,19)=14.3$; $P<0.001]$; olanzapine $[F(3,21)=7.02 ; P<0.01]$. Post hoc analysis showed that clozapine at $3 \mathrm{mg} / \mathrm{kg}(P<0.01)$ and $10 \mathrm{mg} / \mathrm{kg}$ $(P<0.01)$ and olanzapine at $3 \mathrm{mg} / \mathrm{kg}(P<0.01)$ and $10 \mathrm{mg} / \mathrm{kg}$ $(P<0.01)$ significantly increase histamine efflux compared to the vehicle treated group. The increases in mPFC histamine seen after both clozapine and olanzapine at $1 \mathrm{mg} / \mathrm{kg}$ were not statistically significant. After treatment with quetiapine $(20 \mathrm{mg} / \mathrm{kg}$; s.c. $)$ a twoway ANOVA revealed a significant effect of drug $[F(1,90)=14.02$; $P<0.001]$ but no time or drug $\times$ time interaction. Following risperidone $(1 \mathrm{mg} / \mathrm{kg}$; s.c. $)$ both $\operatorname{drug}[F(1,70)=4.747 ; P<0.05]$ and time $[F(9,70)=4.207 ; P<0.001]$ were significant but the interaction between drug $\times$ time was not. Aripiprazole $(10 \mathrm{mg} / \mathrm{kg}$, p.o.) treatment did not significantly affect HA efflux compared to the vehicle treated group. Analysis of the average percent of baseline over the $3.5 \mathrm{~h}$ post-injection of quetiapine, revealed that only quetiapine $(20 \mathrm{mg} / \mathrm{kg})$ significantly increased HA efflux in the mPFC compared to the vehicle treated group $[t(9)=2.819$; $P<0.05]$. Risperidone $(1 \mathrm{mg} / \mathrm{kg})$ induced a slight increase in HA release, however, this failed to reach statistical significance $[t(8)=1.162$; NS $]$. Aripiprazole was without effect on HA release when compared to the vehicle treated group $[t(9)=0.066$; NS].

\section{EFFECT OF TYPICAL ANTIPSYCHOTIC DRUGS ON HISTAMINE EFFLUX IN THE mPFC}

Of the typical antipsychotic drugs tested, Chlorpromazine $(10 \mathrm{mg} / \mathrm{kg})$ and perphenazine $(3 \mathrm{mg} / \mathrm{kg}$ ) were found to significantly elevate HA efflux in the mPFC (see Table 1). A two-way ANOVA revealed significant effect of drug and a significant interaction between drug and time after chlorpromazine treatment: $\operatorname{drug}[F(1,90)=79.27 ; P<0.001]$, time $[F(9,90)=1.15 ; \mathrm{NS}]$, and 

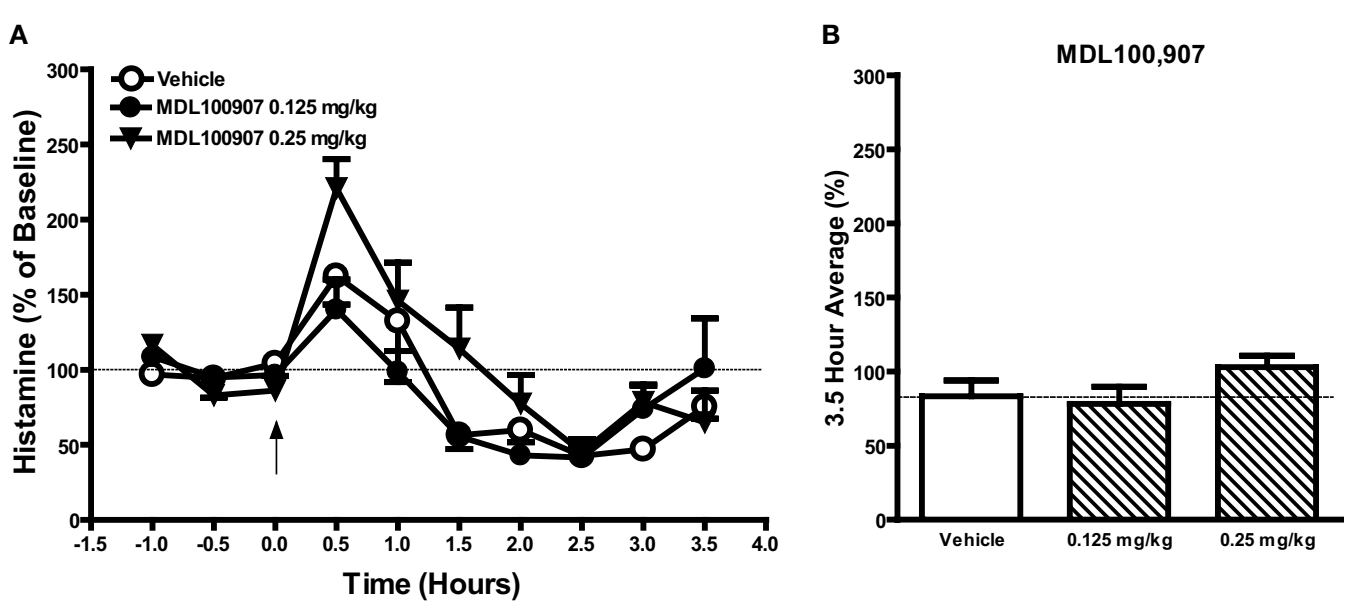

FIGURE 2 | Effects of the selective 5-HT ${ }_{2 A}$ receptor antagonist MDL100907 $(0.125$ and $0.25 \mathrm{mg} / \mathbf{k g}$, s.c.) or vehicle on histamine efflux in the $\mathrm{mPFC}$. Data are mean \pm SEM of the dialyzate HA levels, expressed as a percentage of the baseline. Time course data shown in (A) were analyzed by two-way analysis of variance (ANOVA) followed by post hoc Bonferroni corrected $t$-test. Summary data (B) represent average percent of baseline HA ( \pm SEM) for the $3.5 \mathrm{~h}$ post-drug or vehicle and were subjected to one-way analysis of variance (ANOVA) followed by post hoc Dunnett's corrected $t$-test ( $n=5-6$ per group).
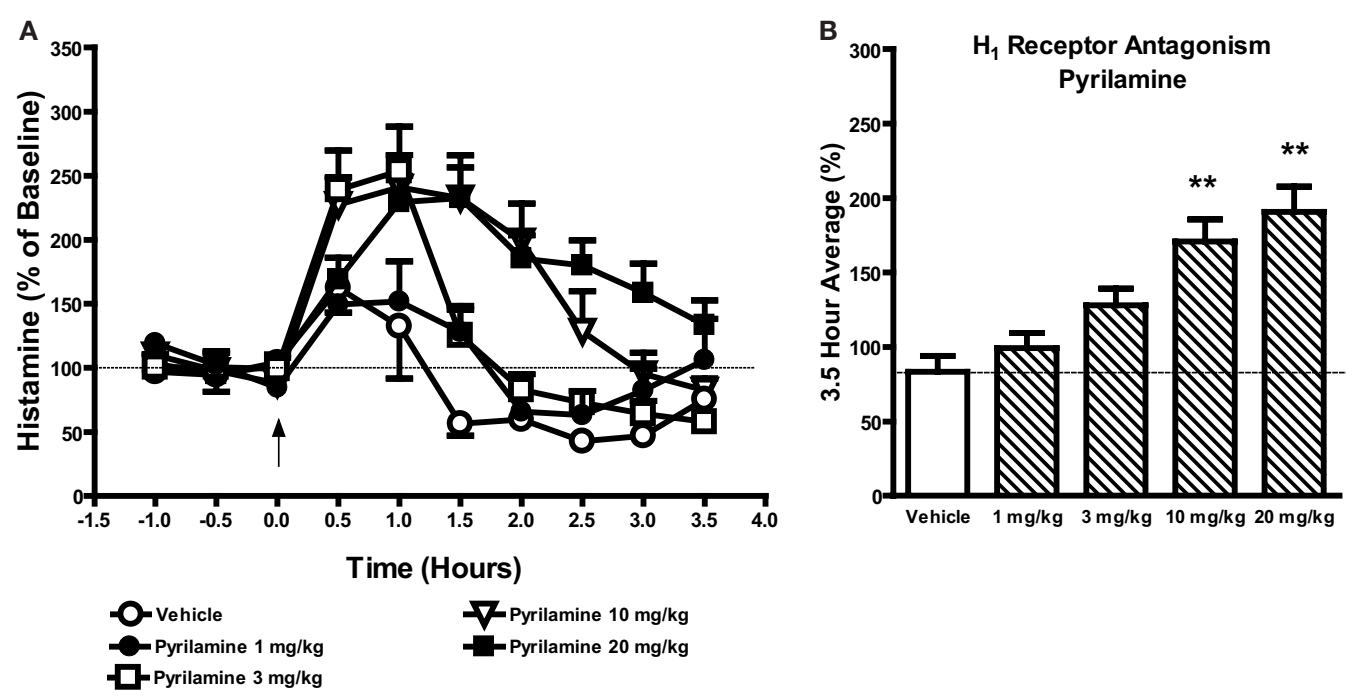

FIGURE 3 | Effects of the selective $\mathrm{H}_{1}$ receptor antagonist pyrilamine $(1-20 \mathrm{mg} / \mathrm{kg}$, s.c.) or vehicle on histamine efflux in the $\mathrm{mPFC}$. Data are mean \pm SEM of the dialyzate HA levels, expressed as a percentage of the baseline. Time course data shown in (A) were analyzed by two-way analysis of variance (ANOVA) followed by post hoc Bonferroni corrected $t$-test. Summary data (B) represent average percent of baseline HA ( \pm SEM) for the $3.5 \mathrm{~h}$ post-drug or vehicle and were subjected to one-way analysis of variance (ANOVA) followed by post hoc Dunnett's corrected $t$-test ( $n=4-6$ per group). ${ }^{*} P<0.01$ compared to the vehicle treated animals. drug $\times$ time $[F(9,90)=4.66 ; P<0.001]$ and perphenazine treatment: drug $[F(1,80=58.47 ; P<0.001]$, time $[F(9,80)=1.94$; NS $]$, and drug $\times$ time $[F(9,80)=3.33 ; P<0.01]$. A two-way ANOVA after haloperidol treatment did not reveal a significant difference between groups. Post hoc analysis showed significant increases in HA efflux after chlorpromazine and perphenazine treatment as compared to the vehicle treated group. Analysis of the average percent of baseline over the $3.5 \mathrm{~h}$ post-injection of drug revealed significant increases in HA efflux compared to the vehicle treated group after treatment with chlorpromazine $[t(9)=4.83$; $P<0.001]$ and perphenazine $[t(8)=4.195 ; P<0.01]$ but not haloperidol $t(7)=0.204$; NS].

\section{EFFECTS OF RECEPTOR SUBTYPE SELECTIVE ANTAGONISTS ON EXTRACELLULAR HISTAMINE IN THE RAT MPFC}

Since most atypical antipsychotic drugs have actions at several receptor, to further explore the underlying mechanism of action of drug induced histamine efflux, we examined the effects of selective compounds for various receptors (see Table 2). Significant increases in HA efflux were observed after the administration of the histamine $\mathrm{H}_{3}$ receptor antagonist ciproxifan $(1 \mathrm{mg} / \mathrm{kg}$, s.c.): drug $[F(1,90)=84.35 ; P<0.001]$, time $[F(9,90)=2.09$; $P<0.05]$, and drug $\times$ time $[F(9,90)=4.57 ; P<0.001]$ and the mixed $5-\mathrm{HT}_{2 \mathrm{~A}} / \mathrm{H}_{1}$ receptor antagonist ketanserin: drug $[F(2$, $120)=10.01 ; P<0.001]$, time $[F(9,120)=13.28 ; P<0.001]$ 

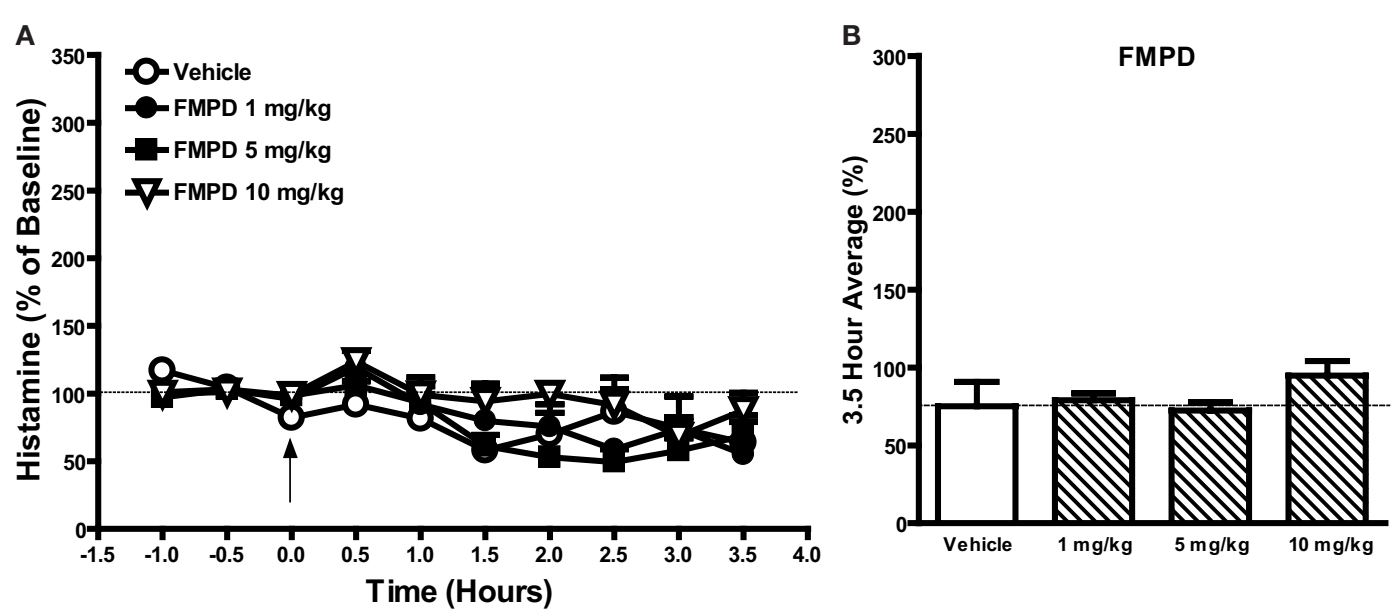

FIGURE 4 |The effects of the potential novel antipsychotic drug FMPD [6-fluoro-10-[3-(2-methoxyethyl)-4-methyl-piperazin-1-yl]-2-methyl-4H-3thia-4,9-diaza-benzo[f]azulene] $(1-10 \mathrm{mg} / \mathrm{kg})$ on histamine efflux in the mPFC. Data are mean \pm SEM of the dialyzate HA levels, expressed as a percentage of the baseline. Time course data shown in (A) FMPD were analyzed by two-way analysis of variance (ANOVA) followed by post hoc Bonferroni corrected $t$-test. Summary data (B) represent average percent of baseline HA ( \pm SEM) for the $3.5 \mathrm{~h}$ post-drug or vehicle and were subjected to one-way analysis of variance (ANOVA) followed by post hoc Dunnett's corrected $t$-test ( $n=6$ per group).

Table 1 |The effect of typical and atypical antipsychotics on histamine efflux in the mPFC.

\begin{tabular}{|c|c|c|c|c|c|}
\hline Drug & Dose (mg/kg) & Route of administration & HA baseline (nM) & HA $\%$ of baseline ( $3.5 \mathrm{~h}$ average) & $P$-value \\
\hline Chlorpromazine & 10 & s.c. & $3.57 \pm 0.13$ & $162.5 \pm 12.5$ & $* *$ \\
\hline Haloperidol & 0.5 & s.c. & $5.03 \pm 0.32$ & $68.53 \pm 8.4$ & n.s. \\
\hline \multirow[t]{2}{*}{ Olanzapine } & 1 & s.c. & $3.50 \pm 0.19$ & $103.2 \pm 12.3$ & n.s. \\
\hline & 3 & s.c. & $4.20 \pm 0.43$ & $163.2 \pm 14.7$ & $* *$ \\
\hline \multirow[t]{3}{*}{ Clozapine } & 1 & s.c. & $5.53 \pm 0.79$ & $114.8 \pm 16.4$ & n.s. \\
\hline & 3 & s.c. & $4.13 \pm 0.40$ & $172.8 \pm 19.1$ & $* *$ \\
\hline & 10 & s.c. & $5.14 \pm 0.29$ & $198.3 \pm 9.1$ & $* *$ \\
\hline Quetiapine & 20 & s.c. & $5.68 \pm 0.27$ & $115.7 \pm 8.2$ & * \\
\hline Risperidone & 1 & s.c. & $6.92 \pm 0.86$ & $92.1 \pm 10.1$ & n.s. \\
\hline Aripiprazole & 10 & p.o. & $3.79 \pm 0.14$ & $70.4 \pm 7.6$ & n.s. \\
\hline
\end{tabular}

${ }^{*} P<0.05,{ }^{*} P<0.01$ compared to the vehicle treated animals.

and there was a drug $\times$ time interaction $[F(18,80)=13.76$; $P<0.05]$. Post hoc analysis revealed significant increases in HA efflux after ciproxifan $(0.5-3.5 \mathrm{~h} ; P<0.05-0.001)$ and ketanserin $4(0.5 \mathrm{~h} ; P<0.05)$ and $8 \mathrm{mg} / \mathrm{kg}$ treatment $(2.5-3.0 \mathrm{~h} ; P<0.05)$ as compared to the vehicle treated group. Subsequent analysis of average percent of baseline over $3.5 \mathrm{~h}$ post-injection of drug revealed that ciproxifan $[t(9)=4.88 ; P<0.001]$ and ketanserin $[F(2,15)=4.87 ; P<0.05)$ at $8 \mathrm{mg} / \mathrm{kg}(P<0.05)$ but not $4 \mathrm{mg} / \mathrm{kg}$ increased mPFC histamine efflux (see Table 2 ). The effect of the selective $5-\mathrm{HT}_{2 \mathrm{~A}}$ receptor antagonist MDL 100907 on HA efflux in the mPFC is shown in Figure 3. A two-way ANOVA revealed an overall effect of drug $[F(2,120)=3.81 ; P<0.05]$ and time
$[F(9,120)=16.7 ; P<0.001]$ but no drug $\times$ time effect $[F(18$, 120) $1.61 ; P>0.05]$. Subsequent Bonferroni post hoc comparisons and analysis of the $3.5 \mathrm{~h}$ average data however did not reveal any significant alterations in histamine efflux in the $\mathrm{mPFC}$ by MDL100907 at either 0.125 or $0.25 \mathrm{mg} / \mathrm{kg}[F(2,15)=1.54$; $P>0.05]$. Additionally we also investigated the effects of the selective $5-\mathrm{HT}_{6}$ receptor antagonist Ro 04-6790 $10 \mathrm{mg} / \mathrm{kg}$ and the $5-\mathrm{HT}_{2 \mathrm{c}}$ antagonist SB242048 $10 \mathrm{mg} / \mathrm{kg}$ on HA efflux in the mPFC. Two-way ANOVA indicated a significant effect of drug following the treatment with Ro 04-6790 $[F(1,81)=4.57 ; P<0.05]$ but not SB242048 $[F(1,81)=2.13$; NS $]$. However, subsequent Bonferroni post hoc comparisons and analysis of the average percent 
Table 2 |The effect of receptor subtype selective drugs on histamine efflux in the mPFC.

\begin{tabular}{|c|c|c|c|c|c|c|}
\hline Drug & Dose (mg/kg) & Route of administration & Receptor target & HA baseline (nM) & $\mathrm{HA} \%$ of baseline ( $3.5 \mathrm{~h}$ average) & $P$-value \\
\hline Vehicle & - & s.c. & - & $3.02 \pm 0.20$ & $75.11 \pm 15.6$ & - \\
\hline Ciproxifan & 1 & s.c. & $\mathrm{H}_{3}$ & $15.29 \pm 0.54$ & $200.7 \pm 20.9$ & ** \\
\hline Diphenhydramine & 20 & s.c. & $\mathrm{H}_{1}$ & $2.49 \pm 0.19$ & $285.1 \pm 13.8$ & $* *$ \\
\hline Triprolidine & 35 & s.c. & $\mathrm{H}_{1}$ & $2.85 \pm 0.12$ & $252.6 \pm 33.4$ & $* *$ \\
\hline \multirow[t]{4}{*}{ Pyrilamine } & 1 & s.c. & $\mathrm{H}_{1}$ & $2.96 \pm 0.18$ & $99.24 \pm 10.19$ & n.s. \\
\hline & 3 & s.c. & $\mathrm{H}_{1}$ & $1.86 \pm 0.10$ & $127.9 \pm 11.3$ & n.s. \\
\hline & 10 & s.c. & $\mathrm{H}_{1}$ & $3.07 \pm 0.18$ & $170.8 \pm 14.8$ & $* *$ \\
\hline & 20 & s.c. & $\mathrm{H}_{1}$ & $3.54 \pm 0.11$ & $190.7 \pm 16.8$ & $* *$ \\
\hline Vehicle & - & s.c. & - & $6.78 \pm 1.0$ & $89.2 \pm 10.7$ & - \\
\hline \multirow[t]{2}{*}{ MDL100907 } & 0.125 & s.c. & $5-\mathrm{HT}_{2 \mathrm{~A}}$ & $4.07 \pm 0.47$ & $78.1 \pm 11.6$ & n.s. \\
\hline & 0.25 & s.c. & $5-\mathrm{HT}_{2 \mathrm{~A}}$ & $1.67 \pm 0.15$ & $103.0 \pm 7.7$ & n.s. \\
\hline Vehicle & - & p.o. & - & $3.00 \pm 0.24$ & $77.1 \pm 6.5$ & - \\
\hline \multirow[t]{2}{*}{ Ketanserin } & 4 & p.o. & $5-\mathrm{HT}_{2 \mathrm{~A}} / \mathrm{H}_{1}$ & $2.07 \pm 0.11$ & $93.8 \pm 7.9$ & n.s. \\
\hline & 8 & p.o. & $5-\mathrm{HT}_{2 \mathrm{~A}} / \mathrm{H}_{1}$ & $5.45 \pm 0.55$ & $124.6 \pm 16.8$ & $*$ \\
\hline Vehicle & - & i.p. & - & $1.56 \pm 0.09$ & $90.5 \pm 8.0$ & - \\
\hline SB242048 & 10 & i.p. & $5-\mathrm{HT}_{2 \mathrm{C}}$ & $3.09 \pm 0.24$ & $104.2 \pm 12.6$ & n.s. \\
\hline Ro 04-6790 & 10 & i.p. & $5-\mathrm{HT}_{6}$ & $2.95 \pm 0.23$ & $106.3 \pm 4.2$ & n.s. \\
\hline
\end{tabular}

${ }^{*} P<0.05,{ }^{*} P<0.01$ compared to the vehicle treated animals.

of baseline over $3.5 \mathrm{~h}$ post-injection of drug did not reveal a significant increase in HA efflux compared to the vehicle control treated group after either Ro 04-6790 $[t(10)=1.294$; NS] or SB242048 $[t(10)=0.6919 ; \mathrm{NS}]$.

As the mixed $5-\mathrm{HT}_{2 \mathrm{~A}} / \mathrm{H}_{1}$ receptor antagonist ketanserin but not the selective $5-\mathrm{HT}_{2 \mathrm{~A}}$ receptor antagonist MDL100907 increased mPFC HA efflux we decided to evaluate the effects of selective histamine $\mathrm{H}_{1}$ receptor antagonists on $\mathrm{HA}$ efflux in the mPFC. As is shown in Figures 4A,B the selective $\mathrm{H}_{1}$ receptor antagonist pyrilamine markedly increased HA efflux in the mPFC. A two-way ANOVA revealed a significant effect of drug $[F(4$, $220)=25.31 ; P<0.001]$, time $[F(9,220)=24.96 ; P<0.001]$, and a drug $\times$ time interaction $[F(36,220)=3.754 ; P<0.001]$. Subsequent post hoc comparisons revealed significant increases in HA efflux after pyrilamine. Analysis of the average percent of baseline over $3.5 \mathrm{~h}$ post-injection of drug revealed that pyrilamine significantly increased HA efflux in the $\operatorname{mPFC}[F(4,26)=11.8$; $P<0.001]$ at $10 \mathrm{mg} / \mathrm{kg}(P<0.01)$ and $20 \mathrm{mg} / \mathrm{kg}(P<0.01)$ but not 1 or $3 \mathrm{mg} / \mathrm{kg}$. Increases in $\mathrm{mPFC} \mathrm{HA}$ efflux was also observed after the administration of two other $\mathrm{H}_{1}$ receptor antagonists triprolidine: $\operatorname{drug}[F(1,90)=73.11 ; P<0.001]$, time $[F(9$, $90)=3.58 ; P<0.001]$, drug $\times$ time $[F(9,90)=4.19 ; P<0.001]$ and diphenhydramine: drug $[F(1,90)=168.2 ; P<0.001]$, time $[F(9,90]=7.38 ; P<0.001]$, drug $\times$ time $[F(9,90)=12.49$; $P<0.001]$. Subsequent analysis of average percent of baseline over $3.5 \mathrm{~h}$ post-injection of drug revealed that triprolidine $[t(9)=3.984 ; P<0.01]$ and diphenhydramine $[t(9)=7.03$; $P<0.001]$ increased mPFC histamine efflux by $\sim 132.6$ and $\sim 185.1 \%$ respectively (see Table 2 ).

EFFECT OF THE PUTATIVE ANTIPSYCHOTIC DRUG FMPD ON HISTAMINE EFFLUX IN THE mPFC

As our earlier findings revealed that selective histamine $\mathrm{H}_{1}$ receptor antagonists such as pyrilamine, triprolidine, and diphenhydramine increased histamine release in the mPFC we questioned whether the increase in mPFC HA efflux observed after treatment with antipsychotic drugs is linked to antagonism of histamine $\mathrm{H}_{1}$ receptors. To test this hypothesis, we evaluated the ability of the potential novel antipsychotic FMPD [6-fluoro-10-[3-(2-methoxyethyl)-4-methyl-piperazin-1yl]-2-methyl-4H-3-thia-4,9-diaza-benzo[f]azulene] to modulate histamine efflux in the mPFC. FMPD was chosen since it has high affinity for dopamine $\mathrm{D}_{2}\left(K_{i} 6.3 \mathrm{nM}\right), 5-\mathrm{HT}_{2 \mathrm{~A}}\left(K_{i} 7.3 \mathrm{nM}\right)$, and $5-\mathrm{HT}_{6}\left(K_{i} 8.0 \mathrm{nM}\right)$ human recombinant receptors but has lower affinity for histamine $\mathrm{H}_{1}\left(K_{i} 30 \mathrm{nM}\right)$ and $5-\mathrm{HT}_{2} \mathrm{C}\left(K_{i}\right.$ $102 \mathrm{nM}$ ) human recombinant receptors than olanzapine (Rasmussen et al., 2005). A two-way ANOVA on the FMPD data indicated a significant effect of drug $[F(3,190)=4.532 ; P<0.01]$ and time $[F(9,190)=8.78 ; P<0.001]$ but no drug $\times$ time interaction. However, Bonferroni post hoc comparisons and analysis of the average percent of baseline over $3.5 \mathrm{~h}$ post-injection of drug FMPD $[1-10 \mathrm{mg} / \mathrm{kg} ; F(3,22)=1.628 ; \mathrm{NS}]$ did not reveal any significant differences between FMPD and the vehicle control group.

\section{EFFECT OF CLOZAPINE OR PYRILAMINE ON HA EFFLUX AFTER LOCAL PERFUSION INTO THE MPFC}

The local perfusion of either clozapine $(1-300 \mu \mathrm{M})$ or pyrilamine $(1-300 \mu \mathrm{M})$ failed to affect histamine efflux in the mPFC (Figure 5).

\section{RELATIONSHIP BETWEEN AFFINITIES FOR RECEPTOR SUBTYPES AND THE ABILITY TO INCREASE EXTRACELLULAR HA LEVELS IN THE mPFC}

In order to further evaluate the individual contribution of receptor subtypes, we examined the relationship between the propensity of the 9 antipsychotic drugs tested to increase extracellular histamine and their affinities at 11 receptors. Of the 11 receptors examined, only the correlations between mPFC HA efflux and $K_{i}$ for histamine $\mathrm{H}_{1}$ receptors $\left(r^{2}=0.649 ; n=16 ; P<0.0001\right)$ and $5-\mathrm{HT}_{6}$ receptors $\left(r^{2}=0.629 ; n=16 ; P<0.0001\right.$; see Figure 6) 


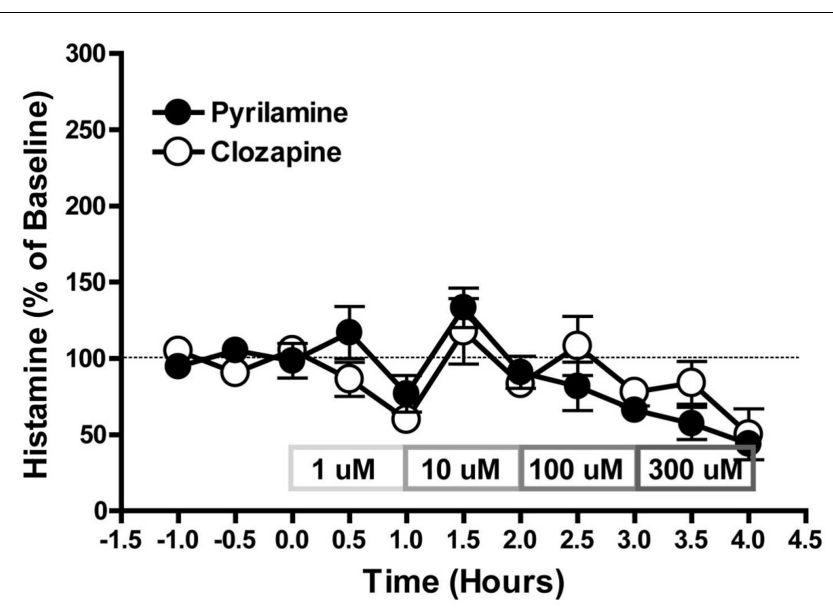

FIGURE 5 |The effect of pyrilamine or clozapine on HA efflux after local perfusion into $\mathrm{mPFC}$. Data are mean $\pm \mathrm{SEM}$ of the dialyzate HA levels, expressed as a percentage of the baseline. $n=5-6$ rats per group.

were statistically significant. However, the correlation with 5-HT6 receptors appears to be co-incidental since the $5-\mathrm{H} 6$ receptors specific compound Ro 46-6760 did not increase HA. There was no correlation with the $K_{i}$ values for $5-\mathrm{HT}_{2 \mathrm{~A}}$ receptors $\left(r^{2}=0.0469\right.$; $n=17$; NS) or other receptor subtypes $\left(\mathrm{D}_{2}, 5-\mathrm{HT}_{1 \mathrm{~A}}, 5-\mathrm{HT}_{2 \mathrm{C}}\right.$, $5-\mathrm{HT}_{7}, \alpha_{1 \mathrm{~A}}, \alpha_{2 \mathrm{~A}}, \alpha_{2 \mathrm{~B}}$, and $\alpha_{2 \mathrm{C}}, \mathrm{H}_{2}$, or $\mathrm{H}_{3}$; Table 3 ).

\section{DISCUSSION}

The present study was undertaken to investigate the effects of atypical antipsychotic drugs on histamine release in the mPFC and to determine the role of individual monoamine receptor subtypes in mediating these effects. The major findings of the present study are: (1) clozapine olanzapine, quetiapine $(20 \mathrm{mg} / \mathrm{kg})$, perphenazine $(3 \mathrm{mg} / \mathrm{kg})$, and chlorpromazine $(10 \mathrm{mg} / \mathrm{kg})$ significantly increased mPFC histamine efflux (2) selective antagonism of $\mathrm{H}_{1}$ and $\mathrm{H}_{3}$ receptors but not $5-\mathrm{HT}_{2 \mathrm{~A}}, 5-\mathrm{HT}_{2} \mathrm{C}$, or $5-\mathrm{HT}_{6}$ receptors markedly increased histamine efflux in the MPFC; (3) the potential novel antipsychotic drug FMPD, which has a similar binding profile to that of olanzapine but with lower affinity for $\mathrm{H}_{1}$ receptors, does not increase histamine efflux in the mPFC (4) for the nine antipsychotic drugs examined, affinity at histamine $\mathrm{H}_{1}$ receptors was significantly correlated with histamine efflux in the $\mathrm{mPFC}$, whereas affinity at most other monoaminergic receptors examined, including $5-\mathrm{HT}_{2 \mathrm{~A}}$, were not.

Atypical antipsychotics drugs, but not typical antipsychotics, have previously been reported to enhance histaminergic activity in brain regions including the $\mathrm{MPFC}$ and striatum, with the differences in the ability to modulate histamine efflux attributed to the greater ability of atypical antipsychotic drugs to antagonize 5- $\mathrm{HT}_{2 \mathrm{~A}}$ receptors. Morisset et al. (1999) hypothesized that in blocking $5-\mathrm{HT}_{2 \mathrm{~A}}$ receptors, atypical antipsychotics relieves histaminergic neurons from tonic serotonergic inhibition. In the present study we observed significant increases in histamine efflux following the administration of olanzapine, clozapine, chlorpromazine, and perphenazine. While all of the antipsychotic drugs which increased mPFC histamine release in this study possess antagonist activity at 5- $\mathrm{HT}_{2 \mathrm{~A}}$ receptors, it is unlikely that antagonism of 5- $\mathrm{HT}_{2 \mathrm{~A}}$ receptors accounts for the observed differences in the ability to modulate histamine efflux. Firstly, we failed to observe a significant stimulation of histamine efflux in the mPFC following the administration of the highly selective $5-\mathrm{HT}_{2 \mathrm{~A}}$ receptor antagonist MDL 100,907 although we did observe an effect with ketanserin which is discussed in a later section. Secondly, we did not observe a significant correlation between affinity at $5-\mathrm{HT}_{2 \mathrm{~A}}$ receptors and mPFC histamine efflux for the nine antipsychotic drugs tested. Thirdly, serotonergic inhibition of histamine release has not been described elsewhere in the literature and previous in vivo microdialysis (Laitinen et al., 1995) and electrophysiology studies (Eriksson et al., 2001) suggest that endogenous 5-HT has a stimulatory not inhibitory effect on histaminergic neurons. For example, 5-HT is known to inhibit the firing of GABA containing ventrolateral preoptic neurons (VPLO) which are primarily activated during sleep and play an important role in the silencing histaminergic neurons. Thus by inhibiting VPLO neurons, serotonin may stimulate histamine release by freeing histaminergic neurons from GABAergic inhibition. Together, these findings argue against a significant role for $5-\mathrm{HT}_{2 \mathrm{~A}}$ receptors in the differential effects of antipsychotics on histamine efflux.

Our data suggest that the differences in the ability of the antipsychotics to modulate histamine efflux are unlikely to be accounted for by interactions with $\mathrm{D}_{2}$ receptors as all of the antipsychotic drugs tested block $\mathrm{D}_{2}$ receptors (although some with lower potency, e.g., clozapine and quetiapine). Antagonism of histamine $\mathrm{H}_{3}$ receptors is also unlikely to underlie the increased histaminergic activity following antipsychotic drugs. Although the selective $\mathrm{H}_{3}$ receptor antagonist ciproxifan significantly increased histamine efflux in the mPFC, we observed increases in histamine efflux following the treatment with several antipsychotic drugs (clozapine, olanzapine, chlorpromazine, perphenazine, and quetiapine) but only clozapine and olanzapine are known to have antagonistic effects at $\mathrm{H}_{3}$ receptors. Furthermore, clozapine and olanzapine $(708 \mathrm{nM}$; and $>1 \mu \mathrm{M}$ respectively; Bymaster et al., 1999) have very low affinity at $\mathrm{H}_{3}$ receptors yet they increase mPFC histamine levels to a degree comparable with ciproxifan which has $\mathrm{nM}$ affinity for $\mathrm{H}_{3}$ receptors. Thus differences in the degree of antagonism of dopamine $\mathrm{D}_{2}$ receptors or $\mathrm{H}_{3}$ receptors by antipsychotic drugs do not appear to account for the observed histamine response to antipsychotic drugs.

In this study we observed a significant increase in histamine efflux following the administration of $5-\mathrm{HT}_{2 \mathrm{~A}}$ antagonist ketanserin, which is in agreement with the increase in brain tMeHA levels in mice reported by Morisset et al. (1999). However, in light of failure of the more selective $5-\mathrm{HT}_{2 \mathrm{~A}}$ receptor antagonist MDL 100,907 to increase histamine efflux in the MPFC and the lack of correlation between $5-\mathrm{HT}_{2 \mathrm{~A}}$ receptor affinity and histamine efflux for the antipsychotic drugs tested, it seems likely that the ability of ketanserin to increase histaminergic activity is mediated by an interaction at another receptor subtype. Indeed, ketanserin is known to have affinities at receptors other than $5-\mathrm{HT}_{2 \mathrm{~A}}$ receptors including 5- $\mathrm{HT}_{2 \mathrm{C}}$ (Wainscott et al., 1996), $\alpha_{1}$ adrenoceptors (Bøgesø et al., 1988), and histamine $\mathrm{H}_{1}$ receptors (Ghoneim et al., 2006). Moreover, ketanserin's affinity for histamine $\mathrm{H}_{1}$ receptors is comparable to that of its affinity at $5-\mathrm{HT}_{2 \mathrm{~A}}$ receptors $(1.8$ and $2 \mathrm{nM}$ 

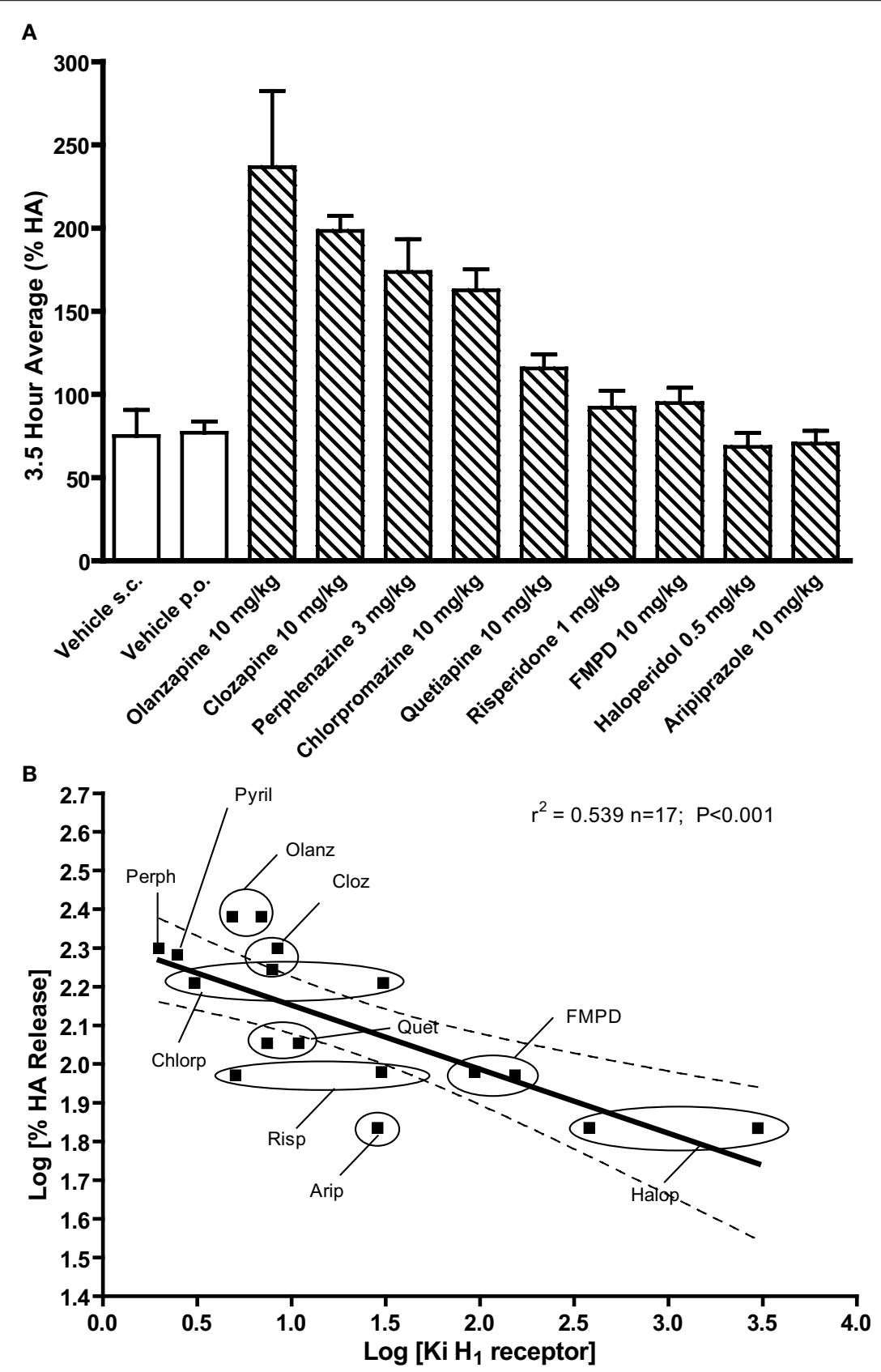

FIGURE 6 | Effects of typical and atypical antipsychotic drugs or vehicle on histamine efflux in the mPFC. Summary data in (A)

represents the mean average percent of baseline HA ( \pm SEM) for the $3.5 \mathrm{~h}$ post-drug or vehicle. Data in (B) shows the correlation between propensity of nine antipsychotic drugs to induce histamine efflux (log
$\% \mathrm{HA})$ in the mPFC and affinity (log $\left.K_{i}\right)$ at histamine $\mathrm{H}_{1}$ receptors. Log $3.5 \mathrm{~h}$ average $\% \mathrm{HA}$ values were plotted against the affinity $\left(\log K_{i}\right)$ at human receptors and where data existed against affinity $\left(\log K_{i}\right)$ at rat receptors. All $K_{i}$ values used are shown in Tables S1 and S2 in Supplementary Material. respectively; Wainscott et al., 1996; Ghoneim et al., 2006). Thus at doses at which ketanserin occupies $5-\mathrm{HT}_{2 \mathrm{~A}}$ receptors, significant occupancy at histamine $\mathrm{H}_{1}$ receptors would also be expected. It should be noted that MDL 100,907 also has affinity for the histamine $\mathrm{H}_{1}$ receptor but this is considerably lower than its affinity for $5-\mathrm{HT}_{2 \mathrm{~A}}$ receptors (66.7 vs $0.84 \mathrm{nM}$; Pehek et al., 2006).

The interaction with histamine $\mathrm{H}_{1}$ receptors by ketanserin is of particularly relevance considering that we observed a significant increase in histamine efflux following the administration of three histamine $\mathrm{H}_{1}$ receptor antagonists (pyrilamine, triprolidine, and diphenhydramine). When administered acutely, the histamine $\mathrm{H}_{1}$ receptor antagonist pyrilamine enhanced histamine efflux in a dose dependent fashion and reached a maximal increase in the mPFC comparable to the histamine $\mathrm{H}_{3}$ receptor antagonist ciproxifan. Furthermore, increases in mPFC histamine efflux were also observed after treatment with additional histamine $\mathrm{H}_{1}$ receptor 
Table 3 | Correlation between propensity of 9 antipsychotic drugs to induce histamine efflux $(\log \% \mathrm{HA})$ in the mPFC and affinity $\left(\log K_{i}\right)$ for 13 receptors.

\begin{tabular}{llll}
\hline Receptor & $\boldsymbol{r}^{\mathbf{2}}$ & $\boldsymbol{n}$ & $\boldsymbol{P}$-value \\
\hline $\mathrm{D}_{2}$ & 0.166 & 17 & $\mathrm{NS}$ \\
$\mathrm{H}_{1}$ & 0.539 & 17 & $<0.001$ \\
$\mathrm{H}_{2}$ & 0.218 & 6 & $\mathrm{NS}$ \\
$\mathrm{H}_{3}$ & 0.127 & 6 & $\mathrm{NS}$ \\
$\alpha_{1 \mathrm{~A}}$ & 0.037 & 9 & $\mathrm{NS}$ \\
$\alpha_{2 \mathrm{~A}}$ & 0.001 & 9 & $\mathrm{NS}$ \\
$\alpha_{2 \mathrm{~B}}$ & 0.337 & 9 & $\mathrm{NS}$ \\
$\alpha_{2 \mathrm{C}}$ & 0.176 & 9 & $\mathrm{NS}$ \\
$5-\mathrm{HT}_{1 \mathrm{~A}}$ & 0.126 & 15 & $\mathrm{NS}$ \\
$5-\mathrm{HT}_{2 \mathrm{~A}}$ & 0.017 & 17 & $\mathrm{NS}$ \\
$5-\mathrm{HT}_{2 \mathrm{C}}$ & 0.158 & 15 & $\mathrm{NS}$ \\
$5-\mathrm{HT}_{6}$ & 0.618 & 18 & $<0.001$ \\
$5-\mathrm{HT}_{7}$ & 0.006 & 15 & $\mathrm{NS}$ \\
\hline
\end{tabular}

Log HA\% of baseline (3.5 h Average) values were plotted against the affinity $\left(\log K_{i}\right)$ at human receptors and where data existed against affinity (log $\left.K_{i}\right)$ at rat receptors. All $K_{i}$ values used are shown in Tables S1 and S2 in Supplementary Material.

antagonists including diphenhydramine and triprolidine. To our knowledge, a stimulatory effect of histamine $\mathrm{H}_{1}$ receptor antagonists on histamine efflux has not been previously shown and the mechanism by which antagonism of histamine $\mathrm{H}_{1}$ receptors leads to enhanced histaminergic neuron activity is currently unknown. Nevertheless, all the antipsychotic drugs examined which increased histamine efflux have high affinity $(<15 \mathrm{nM})$ at the histamine $\mathrm{H}_{1}$ receptor. When we examined the relationship between affinity at histamine $\mathrm{H}_{1}$ receptors and $\mathrm{mPFC}$ histamine efflux we found a highly significant correlation which suggests that antagonism of histamine $\mathrm{H}_{1}$ receptors may mediate the increase in histaminergic neuronal activity following antipsychotic treatment. It should be noted that we also observed a significant correlation between $5-\mathrm{HT}_{6}$ receptor affinity and histamine efflux but this interaction seems unlikely to mediate the effect of antipsychotic drugs on histamine efflux as administration of the selective $5-\mathrm{HT}_{6}$ antagonist Ro 04-6790 failed to increase histamine efflux. In this study we also demonstrated that the potential novel antipsychotic

\section{REFERENCES}

Assié, M. B., Ravailhe, V., Faucillon, V., and Newman-Tancredi, A. (2005). Contrasting contribution of 5-hydroxytryptamine $1 \mathrm{~A}$ receptor activation to neurochemical profile of novel antipsychotics: frontocortical dopamine and hippocampal serotonin release in rat brain. J. Pharmacol. Exp. Ther. 315, 265-272.

Barth, V. N., Chernet, E., Martin, L. J, Need, A. B., Rash, K. S., Morin, M., and Phebus, L. A. (2006). Comparison of rat dopamine D2 receptor occupancy for a series of antipsychotic drugs measured using radiolabeled or nonlabeled raclopride tracer. Life Sci. 78, 3007-3012.

Bentley, J. C., Bourson, A., Boess, F. G., Fone, K. C., Marsden, C. A., Petit, N., and Sleight, A. J. (1999). Investigation of stretching behaviour induced by the selective 5HT6 receptor antagonist, Ro 046790, in rats. Br. J. Pharmacol. 126, 1537-1542.

Bøgesø, K. P., Arnt, J., Boeck, V., Christensen, A. V., Hyttel, J., and Jensen, K. G. (1988). Antihypertensive activity in a series of 1-piperazino-3phenylindans with potent 5-HT2antagonistic activity. J. Med. Chem. 31, 2247-2256.

FMPD which also has high affinity for $5-\mathrm{HT}_{6}$ receptors, has no effect on histamine efflux in the mPFC. Importantly, FMPD has a binding profile similar to that of olanzapine but with lower affinity for histamine $\mathrm{H}_{1}$ receptors (Rasmussen et al., 2005). In general FMPD produces pharmacological effects over a similar dose range to that of olanzapine (Rasmussen et al., 2005), thus FMPD's failure to increase histamine efflux over the dose range $1-10 \mathrm{mg} / \mathrm{kg}$ is unlikely to be due to insufficient target receptor occupancy. Similarly, other antipsychotic drugs with lower affinity at $\mathrm{H}_{1}$ receptors such as haloperidol, risperidone, and aripiprazole also failed to significantly enhance histamine efflux. Together, these findings suggest that the effects of antipsychotic drugs on histamine neuronal activity may be attributable to antagonism of histamine $\mathrm{H}_{1}$ receptors. The location of the histamine $\mathrm{H}_{1}$ receptors, whose blockade mediates the increase in cortical histamine efflux, is unknown. In contrast to their effects after systemic administration, the local perfusion of clozapine or pyrilamine into the $\mathrm{MPFC}$ failed to enhance histamine efflux within the mPFC suggesting that the PFC is not the site of action. Preliminary unpublished observations from our laboratory indicate that perfusion of pyrilamine into the TMN does cause a release of histamine in the PFC but more work is needed to confirm this conclusion.

In summary, by using in vivo microdialysis we have demonstrated that the acute administration of olanzapine, clozapine, quetiapine as well as chlorpromazine and perphenazine increase histamine efflux in the mPFC. The magnitude of histamine efflux observed following the administration of perphenazine or chlorpromazine was comparable to that of atypical antipsychotic drugs such as clozapine or olanzapine. These data therefore suggest that enhanced histaminergic activity is not an exclusive property of atypical antipsychotic drugs. Furthermore, our data suggest that the ability of these drugs to increase histaminergic neuronal activity may be related to their ability to antagonize histamine $\mathrm{H}_{1}$ receptors and is not attributable to antagonism of $5-\mathrm{HT}_{2} \mathrm{~A}$ receptors. The mechanism by which the blockade of histamine $\mathrm{H}_{1}$ receptors leads to increased histamine efflux is unknown and warrants further investigation.

\section{SUPPLEMENTARY MATERIAL}

The Supplementary Material for this article can be found online at http://www.frontiersin.org/Schizophrenia/10.3389/fpsyt.2012. 00049/abstract

Bymaster, F., Perry, K. W., Nelson, D. L., Wong, D. T., Rasmussen, K., Moore, N. A., and Calligaro, D. O. (1999). Olanzapine: a basic science update. Br. J. Psychiatry Suppl. 37, 36-40.

Bymaster, F. P., Calligaro, D. O., Falcone, J. F., Marsh, R. D., Moore, N. A., Tye, N. C., Seeman, P., and Wong, D. T. (1996). Radioreceptor binding profile of the atypical antipsychotic olanzapine. Neuropsychopharmacology 14, 87-96.

Eriksson, K. S., Stevens, D. R., and Haas, H. L. (2001). Serotonin excites tuberomammillary neurons by activation of $\quad \mathrm{Na}(+) / \mathrm{Ca}(2+)$-exchange. Neuropharmacology 40, 345-351.

Fell, M. J., Katner, J. S., Johnson, B. G., Khilevich, A., Schkeryantz, J. M., Perry, K. W., and Svensson, K. A. (2010). Activation of metabotropic glutamate (mGlu)2 receptors suppresses histamine release in limbic brain regions following acute ketamine challenge. Neuropharmacology 58, 632-639.

Ghoneim, O. M., Legere, J. A., Golbraikh, A., Tropsha, A., and Booth, R. G. (2006). Novel ligands for the human histamine $\mathrm{H} 1$ receptor: synthesis, pharmacology, and comparative 
molecular field analysis studies of 2-dimethylamino-5-(6)-phenyl1,2,3,4-tetrahydronaphthalenes. Bioorg. Med. Chem. 14, 6640-6658.

Goudie, A. J., Smith, J. A., and Millan, M. J. (2004). Characterization of the effects of receptorselective ligands in rats discriminating the novel antipsychotic quetiapine. Psychopharmacology (Berl.) 171, 212-222.

Haas, H., and Panula, P. (2003). The role of histamine and the tuberomammillary nucleus in the nervous system. Nat. Rev. Neurosci. 4, 121-130.

Haas, H. L., Sergeeva, O. A., and Selbach, O. (2008). Histamine in the nervous system. Physiol. Rev. 88, 1183-1241.

Huang, M., Li, Z., Dai, J., Shahid, M., Wong, E. H., and Meltzer, H. Y. (2008). Asenapine increases dopamine, norepinephrine, and acetylcholine efflux in the rat medial prefrontal cortex and hippocampus. Neuropsychopharmacology 33, 2934-2945.

Kapur, S., VanderSpek, S. C., Brownlee, B. A., and Nobrega, J. N. (2003). Antipsychotic dosing in preclinical models is often unrepresentative of the clinical condition: a suggested solution based on in vivo occupancy. J. Pharmacol. Exp. Ther. 305, 625-631.

Keefe, R. S., Bilder, R. M., Davis, S. M., Harvey, P. D., Palmer, B. W., Gold, J. M., Meltzer, H. Y., Green, M. F., Capuano, G., Stroup, T. S., McEvoy, J. P., Swartz, M. S., Rosenheck, R. A., Perkins, D. O., Davis, C. E., Hsiao, J. K., and Lieberman, J. A. (2007). Neurocognitive effects of antipsychotic medications in patients with chronic schizophrenia in the CATIE Trial. Arch. Gen. Psychiatry 64, 633-647.

Kuroki, T., Meltzer, H. Y., and Ichikawa, J. (1999). Effects of antipsychotic drugs on extracellular dopamine levels in rat medial prefrontal cortex and nucleus accumbens. J. Pharmacol. Exp. Ther. 288, 774-781.

Laitinen, K. S. M., Tuomisto, L., and Laitinen, J. T. (1995). Endogenous serotonin modulates histamine release in the rat hypothalamus as measured by in vivo microdialysis. Eur. J. Pharmacol. 285, 159.

Le, S., Gruner, J. A., Mathiasen, J. R., Marino, M. J., and Schaffhauser, H. (2008). Correlation between ex vivo receptor occupancy and wakepromoting activity of selective $\mathrm{H} 3$ receptor antagonists. J. Pharmacol. Exp. Ther. 325, 902-909.
Li, X. M., Perry, K. W., Wong, D. T., and Bymaster, F. P. (1998). Olanzapine increases in vivo dopamine and norepinephrine release in rat prefrontal cortex, nucleus accumbens and striatum. Psychopharmacology (Berl). 136, 153-161.

Lovenberg, T. W., Pyati, J., Chang, H., Wilson, S. J., and Erlander, M. G. (2000). Cloning of rat histamine $\mathrm{H}(3)$ receptor reveals distinct species pharmacological profiles. J. Pharmacol. Exp. Ther. 293, 771-778.

Marek, G. J., Martin-Ruiz, R., Abo, A., and Artigas, F. (2005). The selective 5-HT2A receptor antagonist M100907 enhances antidepressantlike behavioral effects of the SSRI fluoxetine. Neuropsychopharmacology 30, 2205-2215.

Meltzer, H. Y., and McGurk, S. R. (1999). The effects of clozapine, risperidone, and olanzapine on cognitive function in schizophrenia. Schizophr. Bull. 25, 233-255.

Meltzer, H. Y., and Okayli, G. (1995). Reduction of suicidality during clozapine treatment of neurolepticresistant schizophrenia: impact on risk-benefit assessment. Am. J. Psychiatry 152, 183-190.

Morisset, S., Sahm, U. G., Traiffort, E., Tardivel-Lacombe, J., Arrang, J. M., and Schwartz, J. C. (1999). Atypical neuroleptics enhance histamine turnover in brain via 5-hydroxytryptamine 2a receptor blockade. J. Pharmacol. Exp. Ther. 288, 590-596.

Natesan, S., Reckless, G. E., Nobrega, J. N., Fletcher, P. J., and Kapur, S. (2006). Dissociation between in vivo occupancy and functional antagonism of dopamine D2 receptors: comparing aripiprazole to other antipsychotics in animal models. Neuropsychopharmacology 31, 1854-1863.

Pehek, E. A., Nocjar, C., Roth, B. L., Byrd, T. A., and Mabrouk, O. S. (2006). Evidence for the preferential involvement of 5-HT2A serotonin receptors in stress- and drug-induced dopamine release in the rat medial prefrontal cortex. Neuropsychopharmacology 31, 265-277.

Peroutka, S. J., Synder, S. H., and Snyder, S. H. (1980). Relationship of neuroleptic drug effects at brain dopamine, serotonin, alphaadrenergic, and histamine receptors to clinical potency. Long-term antidepressant treatment decreases spiroperidol-labeled serotonin receptor binding. Am. J. Psychiatry 137, 1518-1522.

Perry, K. W., Falcone, J. F., Fell, M. J., Ryder, J. W., Yu, H., Love, P. L., Katner, J., Gordon, K. D., Wade, M. R. Man, T., Nomikos, G. G., Phebus, L. A., Cauvin, A. J., Johnson, K. W. Jones, C. K., Hoffmann, B. J., Sandusky, G. E., Walter, M. W., Porter, W. J., Yang, L., Merchant, K. M., Shannon, H. E., and Svensson, K. A. (2008). Neurochemical and behavioral profiling of the selective GlyT1 inhibitors ALX5407 and LY2365109 indicate a preferential action in caudal vs. cortical brain areas. $\mathrm{Neu}$ ropharmacology 55, 743-754.

Rasmussen, K., Benvenga, M. J., Bymaster, F. P., Calligaro, D. O., Cohen, I. R., Falcone, J. F., Hemrick-Luecke, S. K., Martin, F. M., Moore, N. A., Nisenbaum, L. K., Schaus, J. M., Sundquist, S. J., Tupper, D. E., Wiernicki, T. R., and Nelson, D. L. (2005). Preclinical pharmacology of FMPD [6-fluoro-10-[3-(2methoxyethyl)-4-methyl-piperazin1-yl]-2-methyl-4H-3-thia-4,9diaza-benzo[f]azulene]: a potential novel antipsychotic with lower histamine $\mathrm{H} 1$ receptor affinity than olanzapine. J. Pharmacol. Exp. Ther. 315, 1265-1277.

Roth, B. L., Craigo, S. C., Choudhary, M. S., Uluer, A., Monsma, F. J. Jr., Shen, Y., Meltzer, H. Y., and Sibley, D. R. (1994). Binding of typical and atypical antipsychotic agents to 5-hydroxytryptamine-6 and 5-hydroxytryptamine-7 receptors. J. Pharmacol. Exp. Ther. 268 1403-1410.

Roth, B. L., Lopez, E., Beischel, S., Westkaemper, R. B., and Evans, J. M. (2004). Screening the receptorome to discover the molecular targets for plant-derived psychoactive compounds: a novel approach for CNS drug discovery. Pharmacol. Ther. 102, 99-110.

Schwartz, J. C., Arrang, J. M., Garbarg, M., Pollard, H., and Ruat, M. (1991). Histaminergic transmission in the mammalian brain. Physiol. Rev. 71, $1-51$.

Seeman, P., Corbett, R., and Van Tol, H. H. (1997). Atypical neuroleptics have low affinity for dopamine D2 receptors or are selective for D4 receptors. Neuropsychopharmacology 16, 93-110; discussion 111-135.

Seeman, P., and Lee, T. (1975). Antipsychotic drugs: direct correlation between clinical potency and presynaptic action on dopamine neurons. Science 188, 1217-1219.

Wainscott, D. B., Lucaites, V. L., Kursar, J. D., Baez, M., and Nelson, D. L. (1996). Pharmacologic characterization of the human 5-hydroxytryptamine $2 \mathrm{~B}$ receptor: evidence for species differences. J. Pharmacol. Exp. Ther. 276, 720-727.

Westerink, B. H., Cremers, T. I., De Vries, J. B., Liefers, H., Tran, N., and De Boer, P. (2002). Evidence for activation of histamine $\mathrm{H} 3$ autoreceptors during handling stress in the prefrontal cortex of the rat. Synapse 43, 238-243.

Zeng, X. P., Le, F., and Richelson, E. (1997). Muscarinic m4 receptor activation by some atypical antipsychotic drugs. Eur. J. Pharmacol. 321, 349-354.

Zhang, W., Perry, K. W., Wong, D. T., Potts, B. D., Bao, J., Tollefson G. D., and Bymaster, F. P. (2000). Synergistic effects of olanzapine and other antipsychotic agents in combination with fluoxetine on norepinephrine and dopamine release in rat prefrontal cortex. Neuropsychopharmacology 23, 250-262.

Conflict of Interest Statement: The authors declare that the research was conducted in the absence of any commercial or financial relationships that could be construed as a potential conflict of interest.

Received: 20 February 2012; accepted: 24 April 2012; published online: 17 May 2012.

Citation: Fell MJ, Katner JS, Rasmussen K, Nikolayev A, Kuo M-S, Nelson DLG, Perry KW and Svensson KA (2012) Typical and atypical antipsychotic drugs increase extracellular histamine levels in the rat medial prefrontal cortex: contribution of histamine $H_{1}$ receptor blockade. Front. Psychiatry 3:49. doi: 10.3389/fpsyt.2012.00049

This article was submitted to Frontiers in Schizophrenia, a specialty of Frontiers in Psychiatry.

Copyright (C) 2012 Fell, Katner, Rasmussen, Nikolayev, Kuo, Nelson, Perry and Svensson. This is an open-access article distributed under the terms of the Creative Commons Attribution Non Commercial License, which permits noncommercial use, distribution, and reproduction in other forums, provided the original authors and source are credited. 